\title{
Isomers in the Chemistry of Germanium Coordination Compounds
}

\author{
Milan Melník* and Jan Garaj
}

Institute of Natural and Humanities Science, Alexander Dubček University of Trenčín, Studentska 1, 91150 Trenčín, Slovak Republic

\begin{abstract}
The coordination chemistry of germanium covers quite bulk fields, as shown by a survey covering the crystallographic and structural data of over two hundred examples. About ten percent of those complexes exist as distortion isomers and are summarised. These are discussed in terms of the coordination around the germanium(I), germanium(II) and germanium(IV) atoms, and correlations are drawn between donor atoms, bond distances and interbond angles. Distortion isomers differing only by degree of distortion in $\mathrm{Ge}-\mathrm{L}$ and $\mathrm{L}-\mathrm{Ge}-\mathrm{L}$ angles by far prevail. There is an example, which contains within one crystal distortion and coordination isomers, which is rarity.
\end{abstract}

Keywords: Germanium, complexes, distortion isomers, crystal structures.

\section{INTRODUCTION}

The largest use of germanium is in transistor technology, indeed transistor activity was first quantified in this element. While this use is now demisting, the transparency of germanium in the infrared is expanding of its use in optics for windows, prisms and lenses. The coordination chemistry of germanium covers a quite bulk field, as shown by a recent survey covering the crystallographic and structural data of almost two hundred examples [1]. About ten percent of these complexes exists as isomers and are summarised in this review. In this review we analyse and classify these examples. The aim of this presentation is to discuss the factors which could lead to a better understanding of stereochemical interactions within the coordination sphere. The systems discussed have been sorted by nuclearity and subdivided according to the coordination number, of the germanium atom. Within each coordination number, the compounds are listed in order of increasing covalent radius of the principles coordinating ligand atom and increasing complexity of the coordination sphere.

\section{DISTORTION ISOMERISM}

The existence of two or more species, even within the same crystal, differing only by degree of distortion, is typical of general class of distortion isomerism [2].

\subsection{Mononuclear Germanium Compounds}

The crystallographic and structural data for mononuclear germanium distortion isomers are summarised in Table $\mathbf{1 .}$ Purple $\mathrm{Ge}\left(\eta^{4}-\mathrm{tpp}\right)(\mathrm{MeO})_{2}$ is only example, which exists in two isomeric forms, monoclinic [3] and tetragonal [4] and in addition, the monoclinic contains two crystallographicaly independent molecules. A six coordinate environment around each $\mathrm{Ge}(\mathrm{IV})$ is created by one tetradentate tpp ligand $(4 \mathrm{~N})$ and two unidentate $\mathrm{MeO}$ ligands $\left(\mathrm{GeN}_{4} \mathrm{O}_{2}\right)$. The

*Address correspondence to this author at the Institute of Natural and $\mathrm{Hu}-$ manities Science, Alexander Dubček University of Trenčín, Studentska 1, 91150 Trenčín, Slovak Republic; Tel: +421 2 52495239; Fax: +421 2 52493198; E-mail: milan.melnik@stuba.sk former ligand created a plane and the latter occupied axial positions. The structure exhibit a distorted geometry with a compressed tetragonal bipyramidal geometry around each $\mathrm{Ge}(\mathrm{IV})$ atom. The mean value of $\mathrm{Ge}-\mathrm{N}(\mathrm{x} 4)$ and $\mathrm{Ge}-\mathrm{O}$ (x2) bond distances elongated in the order: $11.700 \AA$ (monoclinic, molecule 1) < $11.706 \AA$ (monoclinic, molecule 2$)<$ $11.778 \AA$ (tetragonal).

There are seven derivatives which contains two crystallographically independent molecules within the same crystal. Three of them contain germanium in its +2 oxidation state and all belong to the monoclinic class [5-7]. Each Ge(II) atom is three coordinated.

The X-ray analysis of colourless $\left(\mathrm{NEt}_{3} \mathrm{Bz}\right)\left[\mathrm{GeCl}_{3}\right]$ [5] and (pi) $\left[\mathrm{GeCl}_{3}\right] .0 .5 \mathrm{H}_{2} \mathrm{O}$ [6] shows well separated complex $\left[\mathrm{GeCl}_{3}\right]^{-}$anion, $\mathrm{NEt}_{3} \mathrm{Bz}^{+}$or $\mathrm{pi}^{+}$cation and water molecule. The isolated $\left[\mathrm{GeCl}_{3}\right]^{-}$anions have trigonal pyramidal structure with $\mathrm{Cl}-\mathrm{Ge}-\mathrm{Cl}$ angles in [5] with the mean values of $96.07(3,78)^{\circ}$ (molecule 1) and $96.04(3,2.63)^{\circ}$ molecule 2; and in [6] $95.6(5.3)^{\circ}$ (molecule 1) and $96.5(4,5)^{\circ}$ (molecule 2). (The first number in parenthesis is e.s.d., and the second is maximum deviation from the mean). The mean $\mathrm{Ge}-\mathrm{Cl}$ bond distances in [5] are 2.301 (2.3) and 2.299 (2.6) $\AA$ and in [6] $2.273(7,5)$ and $2.278(7,17) \AA$.

In yellow $\mathrm{GeI}_{2}\left(\mathrm{PPh}_{3}\right)$ [7] a trigonal pyramid around $\mathrm{Ge}(\mathrm{II})$ is created by two iodine atoms and one $\mathrm{PPh}_{3}$ ligand $\left(\mathrm{GeI}_{2} \mathrm{P}\right)$. The $\mathrm{Ge}-\mathrm{I}$ and $\mathrm{Ge}-\mathrm{P}$ bond distances of $2.635 \AA$ (mean) and $2.503 \AA$ in molecule 1 are somewhat shorter than those found in molecule 2 with the values of $2.653 \AA$ (mean) and $2.510 \AA$, respectively. While the I- Ge -I bond angles are equal in the both molecules $\left(99.0(1)^{\circ}\right)$, the mean $\mathrm{I}-\mathrm{Ge}-$ $\mathrm{P}$ bond angles are different with the values of $91.7(1,1.3)^{\circ}$ in the molecule 1 and $94.1(1,4)^{\circ}$ in the molecule 2 . The molecule 1 is somewhat more distorted than molecule 2 .

Remaining four derivatives contain germanium in its +4 oxidation state. In three of them, each Ge(IV) atom has a trigonal bipyramidal geometry and all but one of these exhibit a high degree of distortion due to the incorporation a tetradentate groups [8,9] and terdentate group [10], which span the equatorial and axial position. 
Table 1. Crystallographic and Structural data for Mononuclear Germanium Coordination Compounds - Distortion Isomers ${ }^{\mathrm{a}}$

\begin{tabular}{|c|c|c|c|c|c|c|c|c|c|}
\hline $\begin{array}{l}\text { COMPOUND } \\
\text { (COLOUR) }\end{array}$ & \begin{tabular}{|c|} 
CRYST. CL. \\
SPACE GR. \\
$Z$
\end{tabular} & 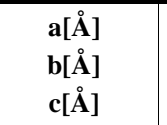 & $\begin{array}{l}\alpha\left[^{\circ}\right] \\
\beta\left[^{\circ}\right] \\
\gamma\left[^{\circ}\right]\end{array}$ & $\begin{array}{c}\text { CHROMO- } \\
\text { PHORE }\end{array}$ & & $\begin{array}{l}e-\mathbf{L} \\
{[\AA ̊]}\end{array}$ & & $\begin{array}{c}\mathbf{L}-\mathbf{G e}-\mathbf{L} \\
{\left[{ }^{\circ}\right]}\end{array}$ & REF. \\
\hline $\begin{array}{l}\alpha-\mathrm{Ge}\left(\eta^{4}-\mathrm{tpp}\right) \cdot(\mathrm{MeO})_{2} \\
(\text { purple })\end{array}$ & $\begin{array}{l}\mathrm{m} \\
\mathrm{P} 2_{1} / \mathrm{c} \\
4\end{array}$ & $\begin{array}{r}15.013(3) \\
14.441(5) \\
8.414(4)\end{array}$ & $91.85(2)$ & $\begin{array}{l}\mathrm{Ge}^{\mathrm{IV}} \mathrm{N}_{4} \mathrm{O}_{2} \\
\mathrm{Ge}^{\mathrm{IV}} \mathrm{N}_{4} \mathrm{O}_{2}\end{array}$ & $\begin{array}{r}\eta^{4} \mathrm{~N}_{\mathrm{eq}}^{\mathrm{b}} \\
\mathrm{MeO}_{\mathrm{ax}} \eta^{4} \mathrm{~N}_{\mathrm{eq}} \\
\mathrm{MeO}_{\mathrm{ax}}\end{array}$ & \begin{tabular}{|l}
$2.010(4.0)$ \\
$2.019(4,0)$ \\
$1.821(3)$ \\
$2.011(4,0)$ \\
$2.020(4,0)$ \\
$1.822(3)$
\end{tabular} & $\begin{array}{c}\mathrm{N}, \mathrm{N}^{\mathrm{b}} \\
\mathrm{N}, \mathrm{O} \\
\\
\mathrm{N}, \mathrm{N} \\
\mathrm{N}, \mathrm{O}\end{array}$ & $\begin{array}{l}89.1(2)^{\mathrm{c}} \\
91.5(2,2.6) \\
90(1,2)^{\mathrm{c}} \\
91.5(2,2.6)\end{array}$ & [3] \\
\hline $\begin{array}{l}\beta-\mathrm{Ge}\left(\eta^{4}-\mathrm{tpp}\right) \cdot(\mathrm{MeO})_{2} \\
\text { (purple) }\end{array}$ & $\begin{array}{l}\mathrm{tg} \\
\mathrm{P} 4_{2} / \mathrm{n} \\
4\end{array}$ & $\begin{array}{l}19.413(2) \\
9.972(1)\end{array}$ & & $\mathrm{Ge}^{\mathrm{IV}} \mathrm{N}_{4} \mathrm{O}_{2}$ & $\begin{array}{c}\eta^{4} \mathrm{~N}_{\mathrm{eq}} \\
\mathrm{MeO}_{\mathrm{ax}}\end{array}$ & $\begin{array}{l}2.022(3,0) \\
2.041(3,0) \\
1.826(3,0)\end{array}$ & $\begin{array}{l}\mathrm{N}, \mathrm{N} \\
\mathrm{O}, \mathrm{O} \\
\mathrm{N}, \mathrm{O}\end{array}$ & $\begin{array}{c}90.0(1,2)^{\mathrm{c}} \\
180.0(1,0) \\
180.0(1) \\
90.0(1,3.4)\end{array}$ & [4] \\
\hline $\begin{array}{l}\left(\mathrm{NEt}_{3} \mathrm{Bz}\right)\left[\mathrm{GeCl}_{3}\right] \\
(\text { colourless }) \\
\text { at } 203 \mathrm{~K}\end{array}$ & $\begin{array}{l}\mathrm{m} \\
\mathrm{P} 2_{1} / \mathrm{c} \\
8\end{array}$ & $\begin{array}{r}25.706(3) \\
7.040(1) \\
20.037(2)\end{array}$ & $112.48(1)$ & $\begin{array}{l}\mathrm{Ge}^{\mathrm{II}} \mathrm{Cl}_{3} \\
\mathrm{Ge}^{\mathrm{II}} \mathrm{Cl}_{3}\end{array}$ & $\mathrm{Cl}$ & $\begin{array}{l}2.301(2,3) \\
2.299(2,6)\end{array}$ & $\begin{array}{l}\mathrm{Cl}, \mathrm{Cl} \\
\mathrm{Cl}, \mathrm{Cl}\end{array}$ & $\begin{array}{l}96.07(5,78) \\
96.04(5,2.6)\end{array}$ & [5] \\
\hline $\begin{array}{l}\mathrm{GeI}_{2}\left(\mathrm{PPh}_{3}\right) \\
\text { (yellow) }\end{array}$ & $\begin{array}{l}\mathrm{m} \\
\mathrm{P} 2_{1} / \mathrm{n} \\
8\end{array}$ & $\begin{array}{l}13.546(4) \\
10.415(5) \\
13.893(4)\end{array}$ & & $\begin{array}{l}\mathrm{Ge}^{\mathrm{II}} \mathrm{I}_{2} \mathrm{P} \\
\mathrm{Ge}^{\mathrm{II}} \mathrm{I}_{2} \mathrm{P}\end{array}$ & $\begin{array}{r}\mathrm{I} \\
\mathrm{Ph}_{3} \mathrm{P} \\
\mathrm{I} \\
\mathrm{Ph}_{3} \mathrm{P}\end{array}$ & $\begin{array}{l}2.635(3,2) \\
2.503(4) \\
2.653(3,8) \\
2.510(5)\end{array}$ & $\begin{array}{r}\mathrm{I}, \mathrm{I} \\
\mathrm{I}, \mathrm{P} \\
\mathrm{I}, \mathrm{I} \\
\mathrm{I}, \mathrm{P}\end{array}$ & $\begin{array}{l}99.0(1) \\
91.7(1,1.3) \\
99.0(1) \\
94.1(1,4)\end{array}$ & [7] \\
\hline $\begin{array}{l}\mathrm{Ge}\left\{\eta^{4}-\mathrm{N}\left(\mathrm{CH}_{2}\right.\right. \\
\left.\left.\mathrm{CH}_{2} \mathrm{O}\right)_{3}\right\}(\mathrm{OH}) \\
(\text { colourless })\end{array}$ & $\begin{array}{l}\mathrm{m} \\
\mathrm{P} 2_{1} / \mathrm{c} \\
8\end{array}$ & $\begin{array}{l}14.156(5) \\
11.002(3) \\
14.682(5)\end{array}$ & $112.63(2)$ & $\begin{array}{l}\mathrm{Ge}^{\mathrm{IV}} \mathrm{O}_{4} \mathrm{~N} \\
\mathrm{Ge}^{\mathrm{IV}} \mathrm{O}_{4} \mathrm{~N}\end{array}$ & $\begin{array}{r}\eta^{4} \mathrm{O}_{\mathrm{eq}} \\
\mathrm{N}_{\mathrm{ap}} \\
\mathrm{HO}_{\mathrm{ap}} \\
\\
\eta^{4} \mathrm{O}_{\mathrm{eq}} \\
\mathrm{N}_{\mathrm{ap}} \\
\mathrm{HO}_{\mathrm{ap}}\end{array}$ & \begin{tabular}{|l|}
$1.786(7,14)$ \\
$2.166(6)$ \\
$1.767(6)$ \\
\\
$1.788(7,11)$ \\
$2.185(6)$ \\
$1.763(8)$
\end{tabular} & $\begin{array}{l}\mathrm{O}, \mathrm{O} \\
\mathrm{O}, \mathrm{N} \\
\mathrm{O}, \mathrm{O} \\
\mathrm{O}, \mathrm{N}\end{array}$ & $\begin{array}{c}96.4(3,1.8) \\
118.8(3,4) \\
83.6(3,6)^{\mathrm{d}} \\
178.8(3) \\
96.5(3,1.6) \\
118.8(3,1.1) \\
83.6(3,2)^{\mathrm{d}} \\
178.3(3) \\
\end{array}$ & [8] \\
\hline $\begin{array}{l}\mathrm{Ge}\left\{\eta^{3}-\mathrm{O}\left(\mathrm{CH}_{2} .\right.\right. \\
\left.\left.\mathrm{CH}_{2} \mathrm{~S}\right)_{2}\right\} \mathrm{Cl}_{2} \\
\text { (colourless) }\end{array}$ & $\begin{array}{l}\text { or } \\
\text { Pca2 } 2_{1} \\
8\end{array}$ & $\begin{array}{l}13.546(4) \\
10.415(5) \\
13.893(4)\end{array}$ & & $\begin{array}{l}\mathrm{Ge}^{\mathrm{IV}} \mathrm{Cl}_{2} \mathrm{~S}_{2} \mathrm{O} \\
\mathrm{Ge}^{\mathrm{IV}} \mathrm{Cl}_{2} \mathrm{~S}_{2} \mathrm{O}\end{array}$ & $\begin{array}{r}\mathrm{Cl}_{\mathrm{eq}} \\
\eta^{3} \mathrm{~S}_{\mathrm{eq}} \\
\mathrm{O}_{\mathrm{ap}} \\
\mathrm{Cl}_{\mathrm{ap}} \\
\\
\mathrm{Cl}_{\mathrm{eq}} \\
\eta^{3} \mathrm{~S}_{\mathrm{eq}} \\
\mathrm{O}_{\mathrm{ap}} \\
\mathrm{Cl}_{\mathrm{ap}}\end{array}$ & \begin{tabular}{|l|}
$2.179(4)$ \\
$2.184(4,15)$ \\
$2.36(1)$ \\
$2.212(4)$ \\
\\
\\
$2.131(6)$ \\
$2.185(4,32)$ \\
$2.39(1)$ \\
$2.204(4)$
\end{tabular} & $\begin{array}{r}\mathrm{Cl}, \mathrm{Cl} \\
\mathrm{S}, \mathrm{S} \\
\mathrm{Cl}, \mathrm{S} \\
\mathrm{Cl}, \mathrm{O} \\
\\
\mathrm{S}, \mathrm{O} \\
\mathrm{Cl}, \mathrm{Cl} \\
\mathrm{S}, \mathrm{S} \\
\mathrm{Cl}, \mathrm{S} \\
\mathrm{Cl}, \mathrm{O} \\
\\
\mathrm{S}, \mathrm{O}\end{array}$ & $\begin{array}{l}101.0(2) \\
130.7(2) \\
104.1(2,9.9) \\
85.3(3) \\
172.8(3) \\
81.0(3,7)^{\mathrm{d}} \\
103.3(2) \\
129.4(2) \\
103.8(2,10.7) \\
87.1(3) \\
169.3(3) \\
81.0(3,1.3)^{\mathrm{d}}\end{array}$ & {$[10]$} \\
\hline $\begin{array}{l}\mathrm{Ge}\left(\eta^{4}-\mathrm{tpp}\right)(\mathrm{MeO})_{2} \\
\text { (purple) }\end{array}$ & $\begin{array}{l}\mathrm{m} \\
\mathrm{P} 2_{1} / \mathrm{c} \\
4\end{array}$ & $\begin{array}{r}15.911(5) \\
14.441(5) \\
8.414(4)\end{array}$ & $91.85(2)$ & $\begin{array}{l}\mathrm{Ge}^{\mathrm{IV}} \mathrm{N}_{4} \mathrm{O}_{2} \\
\mathrm{Ge}^{\mathrm{IV}} \mathrm{N}_{4} \mathrm{O}_{2}\end{array}$ & $\begin{array}{r}\eta^{4} \mathrm{~N}_{\mathrm{eq}} \\
\mathrm{MeO}_{\mathrm{ax}} \\
\eta^{4} \mathrm{~N}_{\mathrm{eq}} \\
\mathrm{MeO}_{\mathrm{ax}}\end{array}$ & \begin{tabular}{|l|}
$2.010(4,0)$ \\
$2.019(4,0)$ \\
$1.821(3,0)$ \\
$2.011(4,0)$ \\
$2.020(4,0)$ \\
$1.822(3,0)$ \\
\end{tabular} & $\begin{array}{l}\mathrm{N}, \mathrm{N} \\
\mathrm{N}, \mathrm{O} \\
\\
\mathrm{N}, \mathrm{N} \\
\mathrm{N}, \mathrm{O}\end{array}$ & $\begin{array}{l}89.1(2)^{c} \\
92.8(2,6) \\
90.5(1)^{c} \\
91.5(2,2.6)\end{array}$ & [3] \\
\hline
\end{tabular}


(Table 1). Contd.....

\begin{tabular}{|c|c|c|c|c|c|c|c|c|c|}
\hline $\begin{array}{l}\mathrm{Ge}\left(\eta^{4}-\mathrm{tpp}\right)(\mathrm{EtO})_{2} \\
\text { (red violet) } \\
\text { at } 130 \mathrm{~K}\end{array}$ & \begin{tabular}{|l}
$\operatorname{tr}$ \\
$\mathrm{P}-1$ \\
2
\end{tabular} & $\begin{array}{l}10.941(1) \\
11.212(1) \\
17.015\end{array}$ & $\begin{array}{l}89.53(1) \\
73.77(1) \\
70.78(1)\end{array}$ & $\begin{array}{l}\mathrm{Ge}^{\mathrm{IV}} \mathrm{N}_{4} \mathrm{O}_{2} \\
\mathrm{Ge}^{\mathrm{IV}} \mathrm{N}_{4} \mathrm{O}_{2}\end{array}$ & $\begin{array}{l}\eta^{4} \mathrm{~N}_{\mathrm{eq}} \\
\mathrm{EtO}_{\mathrm{ax}} \\
\eta^{4} \mathrm{~N}_{\mathrm{eq}} \\
\mathrm{EtO}_{\mathrm{ax}}\end{array}$ & $\begin{array}{l}2.013(3,0) \\
2.023(3,0) \\
1.865(3,0) \\
2.016(3,0) \\
2.029(3,0) \\
1.845(3,0) \\
\end{array}$ & $\begin{array}{l}\mathrm{N}, \mathrm{O} \\
\mathrm{N}, \mathrm{O}\end{array}$ & $\begin{array}{l}88.0(1,2)^{\mathrm{c}} \\
90.0(1,2.5)^{\mathrm{c}}\end{array}$ & [11] \\
\hline $\begin{array}{l}\left(\mathrm{NMe}_{4}\right)\left[\mathrm{GeCl}_{3}\right] \\
\text { (colourless) }\end{array}$ & $\begin{array}{l}\text { or } \\
\text { Pna2 } 2_{1} \\
4\end{array}$ & $\begin{array}{r}13.096(2) \\
8.895(1) \\
9.115(1)\end{array}$ & & $\mathrm{Ge}^{\mathrm{II}} \mathrm{Cl}_{3}$ & $\mathrm{Cl}$ & $\begin{array}{l}2.262(8) \\
2.310(8,11)\end{array}$ & $\mathrm{Cl}, \mathrm{Cl}$ & $95.2(3,6)$ & {$[12,13]$} \\
\hline at $438 \mathrm{~K}$ & $\begin{array}{l}\mathrm{c} \\
\mathrm{Pm} 3 \mathrm{~m} \\
1\end{array}$ & $6.522(2)$ & & $\mathrm{Ge}^{\mathrm{II}} \mathrm{Cl}_{3}$ & & & & & {$[12]$} \\
\hline at $190 \mathrm{~K}$ & $\begin{array}{l}\text { or } \\
\text { Pnam } \\
4 \\
\end{array}$ & $\begin{array}{r}13.083(6) \\
8.841(4) \\
9.027(4)\end{array}$ & & $\mathrm{Ge}^{\mathrm{II}} \mathrm{Cl}_{3}$ & & & & & {$[14]$} \\
\hline
\end{tabular}

Footnotes:

${ }^{\text {a }}$ Where more than one chemically equivalent distance or angle is present, the mean value is tabulated. The first member in parentheses is the e.s.d., and the second one is the maximum deviation from the mean.

${ }^{\mathrm{b}}$ The chemical identity of the coordinated atom or ligand is specified in the columns.

${ }^{\mathrm{c}}$ The six-membered metallocyclic ring.

${ }^{\mathrm{d}}$ The four - membered metallocyclic ring.

In $\mathrm{Ge}\left\{\eta^{4}-\mathrm{N}\left(\mathrm{CH}_{2} \mathrm{CH}_{2} \mathrm{O}\right)_{3}\right\} \mathrm{X}(\mathrm{X}-\mathrm{OH}[8]$ or $\mathrm{Br}$ [9]), while three $\mathrm{O}$ atoms of tetradentate ligand occupied an equatorial position, and the $\mathrm{N}$ atom an axial position and the other axial position is occupy by $\mathrm{X}$ ligand. The mean values of $\mathrm{Ge}-\mathrm{L}$ bond distances in molecule 1 vs molecule 2 in [8] are 1.786 $(7,14)$ vs $1.788(7,11) \AA\left(\mathrm{Ge}-\mathrm{O}_{\text {eq }}\right) ; 2.166(6)$ vs $2.185(6) \AA$ $\left(\mathrm{Ge}-\mathrm{N}_{\mathrm{ax}}\right) ; 1.767(6)$ vs $1.763(6) \AA\left(\mathrm{Ge}-\mathrm{OH}_{\mathrm{ax}}\right)$; and in [9] the values are $1.795(17,19)$ vs $1.766(17,40) ; 2.090(20)$ vs 2.097(19) $\AA, 2.369(4)$ vs $2.363(4) \AA\left(\mathrm{Ge}-\mathrm{Br}_{\mathrm{ax}}\right)$.

In $\mathrm{Ge}\left\{\eta^{3}-\mathrm{O}\left(\mathrm{CH}_{2} \mathrm{CH}_{2} \mathrm{~S}\right)_{2}\right\} \mathrm{Cl}_{2}$ [10] two $\mathrm{S}$ atoms of terdentate ligand occupied an equatorial position and $\mathrm{O}$ atom axial position. One chlorine atom complete trigonal plane and the other one an axial. The $\mathrm{Ge}-\mathrm{L}$ bond distances in molecule 1 vs molecule 2 are: $2.184(4,15)$ vs $2.185(4,32) \AA\left(\mathrm{Ge}-\mathrm{S}_{\mathrm{eq}}\right)$. $2.179(4)$ vs $2.131(6) \AA\left(\mathrm{Ge}-\mathrm{Cl}_{\mathrm{eq}}\right), 2.36(1)$ vs $2.39(1) \AA(\mathrm{Ge}$ - $\left.\mathrm{O}_{\mathrm{ap}}\right)$ and 2.212(4) vs 2.204(4) $\AA\left(\mathrm{Ge}-\mathrm{Cl}_{\mathrm{ap}}\right)$.

A six coordinate environment around Ge(IV) in red violet $\mathrm{Ge}\left(\eta^{4}-\mathrm{tpp}\right)(\mathrm{EtO})_{2}$ [11] is created by one tetradentate tpp and two unidenate EtO ligands $\left(\mathrm{GeN}_{4} \mathrm{O}_{2}\right)$. The mean $\mathrm{Ge}-$ $\mathrm{N}_{\mathrm{eq}}$ and $\mathrm{Ge}-\mathrm{O}_{\mathrm{ax}}$ bond distances are 2.018(3,5) and $1.865(3,0) \AA$ in molecule 1 and 2.022(3,7) and 1.845(3,0) $\AA$ in molecule 2. Each Ge(IV) atom has a compressed tetragonal bipyramidal environment with a different degree of distortion (Table 1).

Colourless $\left(\mathrm{NMe}_{4}\right)\left[\mathrm{GeCl}_{3}\right]$ [12-14] has been studied at different temperatures. At $424 \mathrm{~K}$ the modification is cubic [12], at $293 \mathrm{~K}$ is orthorhombic [12,13], at $190 \mathrm{~K}$ is also orthorhombic [14] and at $160 \mathrm{~K}$ is monoclinic [14]. Each $\mathrm{Ge}(\mathrm{II})$ has a trigonal pyramidal environment $\left(\mathrm{GeCl}_{3}\right)$ with the mean $\mathrm{Ge}-\mathrm{Cl}$ bond distance in the orthorhombic case of $2.294(8,32) \AA$ which is somewhat shorter than that found in the monoclinic case $(2.305(3,0) \AA$ ) (Table 1).

The data in Table 1 shows the mean Ge(II) - L bond distance increases with the atomic size of $\mathrm{L}$ in the sequence:
$2.285 \AA(\mathrm{Cl}, 0.99 \AA)<2.507 \AA(\mathrm{P}, 1.06 \AA)<2.644 \AA(\mathrm{I}$, $1.33 \AA$ ) in 3-coordinate derivatives. In Ge(IV) - L mean bond length, the following trends are apparent:

5-coordinate: $1.765 \AA\left(\mathrm{OH}_{\mathrm{ax}}\right)<2.155 \AA\left(\mathrm{Cl}_{\mathrm{eq}}\right)<2.2 \mathrm{O} 8 \AA$ $\left(\mathrm{Cl}_{\mathrm{ax}}\right)<2.361 \AA\left(\mathrm{Br}_{\mathrm{ax}}\right)$ (unidentate); $2.185 \AA\left(\mathrm{S}_{\mathrm{eq}}\right)<2.375 \AA$ $\left(\mathrm{O}_{\mathrm{ax}}\right)($ terdentate $2 \mathrm{~S}+\mathrm{O}) ; 1.784 \AA\left(\mathrm{O}_{\mathrm{eq}}\right)<2.135 \AA\left(\mathrm{N}_{\mathrm{ax}}\right)$ (tetradentae $3 \mathrm{O}+\mathrm{N})$.

Both electronic and steric factors affect the bonding of the chelated ligands as can be seen in the opening of the $\mathrm{L}$ $\mathrm{Ge}(\mathrm{IV})-\mathrm{L}$ bond angle of the respective metallocycles. The mean $\mathrm{L}-\mathrm{Ge}(\mathrm{IV})-\mathrm{L}$ bond angle opens in the order of the respective metallocycles: $81.0^{\circ}$ (-OCS-) $<83.6^{\circ}(-\mathrm{OCN}-)<$ $90.0^{\circ}\left(-\mathrm{NC}_{3} \mathrm{~N}-\right)$.

\subsection{Di - and Oligonuclear Germanium Compounds}

There are eight derivatives which contain two crystallographicaly independent molecules (Table 2). Three of them are binuclear. Yellow $\left[\mathrm{Ge}\left(\mathrm{SiMeiPr}_{2}\right)_{2}\right]_{2}[15]$ shows near planar geometry around the $\mathrm{Ge}=\mathrm{Ge}$ bond enforced by the triallylsilyl derivatives. The geometry of the complex is transbent with averaged bonding angle of $6.5^{\circ}$. No twisting was observed. The complex contains two crystallographically independent binuclears with $\mathrm{Ge}=\mathrm{Ge}$ bond lengths of 2.266(1) and 2.268(2) $\AA$ and mean Ge - Si bond lengths of $2.403(2)$ and 2.400(2) $\AA$, respectively.

In colourless $\left[\mathrm{Ge}(\mu-\mathrm{O})\left\{\mathrm{N}\left(\mathrm{SiMe}_{3}\right)_{2}\right\}_{2}\right]_{2} \quad$ [16] distorted edge-shared tetraedra are joined by two $\mathrm{O}$ atoms which serve as bridges. Two crystallographically independent binuclears are differing from each other by degree of distortion. The $\mathrm{Ge}$ - $\mathrm{Ge}, \mathrm{Ge}-\mu \mathrm{O}$ and $\mathrm{Ge}-\mathrm{N}$ bond distances (molecule 1 vs molecule 2) are 2.606(2) vs 2.608(2) $\AA, 1.805(9)$ vs $1.805(9)$ $\AA$, and $1.919(11)$ vs $1.826(11) \AA$, respectively. The Ge - O$\mathrm{Ge}, \mu \mathrm{O}-\mathrm{Ge}-\mu \mathrm{O}$ and $\mathrm{N}-\mathrm{Ge}-\mathrm{N}$ bond angles are: 91.8(4) vs $93: 2(4)^{\circ}, 88.1(5)$ vs $86.7(5)$ and $115.3(5)$ vs $114.7(5)^{\circ}$. 
Table 2. Crystallographic and Structural Data for Bi- and Oligonuclear Germanium Coordination Compounds - Distortion Isomers

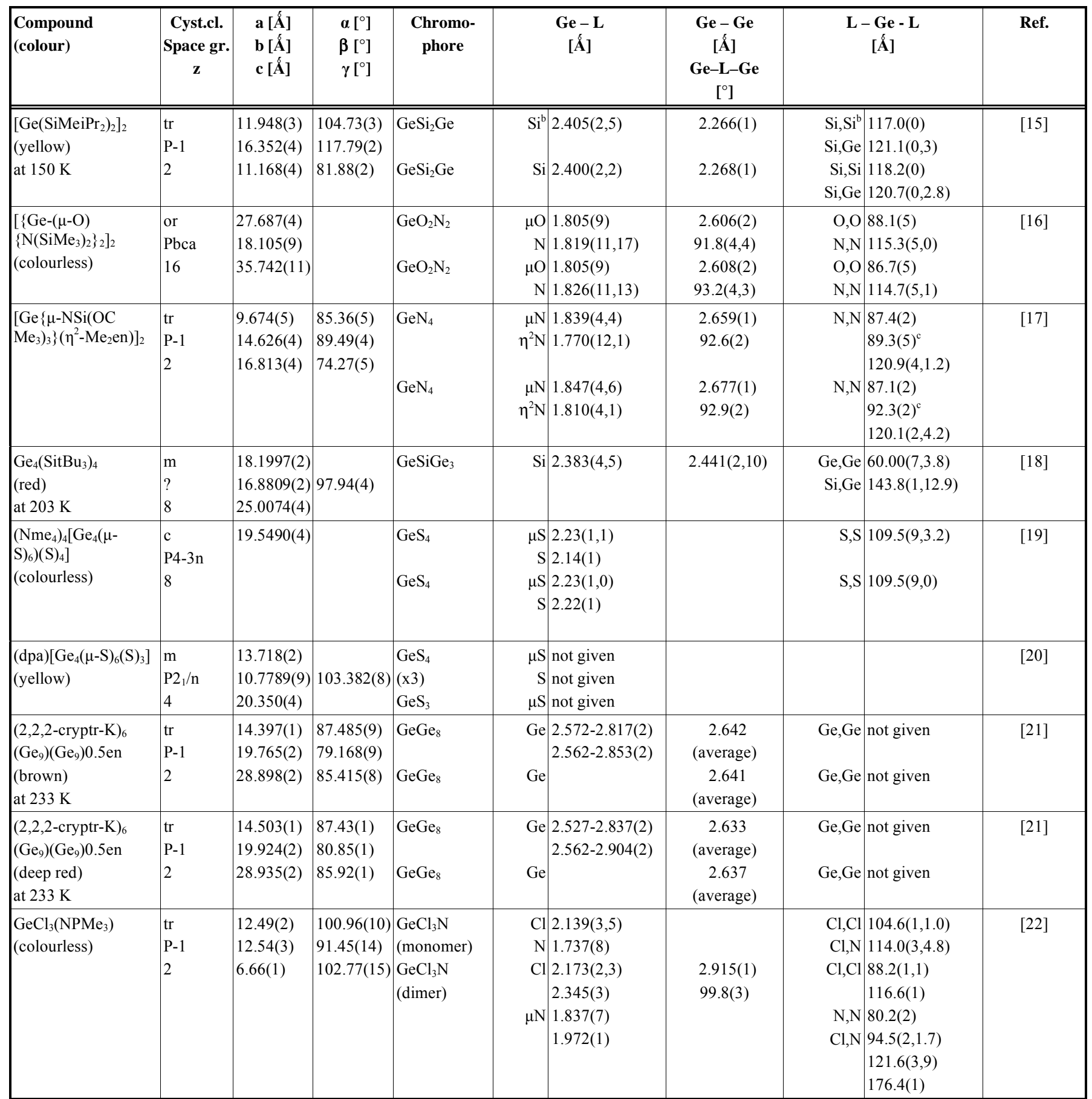

Footnotes:

${ }^{a}$ Where more than one chemically equivalent distance or angle is present, the mean value is tabulated. The first member in parentheses is the e.s.d., and the second one is the maximum deviation from the mean.

${ }^{\mathrm{b}}$ The chemical identity of the coordinated atom or ligand is specified in the columns.

${ }^{\mathrm{c}}$ The five -membered metallocyclic ring.

Structure of colourless $\left[\mathrm{Ge}\left\{\mu-\mathrm{NSi}\left(\mathrm{OCMe}_{3}\right)_{3}\right\}\left(\eta^{2}-\right.\right.$ $\left.\left.\mathrm{Me}_{2} \mathrm{en}\right)\right]_{2}[17]$ contains two edge-shared tetrahedral which are joined by two $\mathrm{N}$-donor $\mathrm{NSi}\left(\mathrm{OCMe}_{3}\right)_{3}$ ligands which serve as bridges. Chelated $\mathrm{Me}_{2}$ en ligand completed a tetrahedral environment around each germanium atom $\left(\mathrm{GeN}_{4}\right)$. The $\mathrm{Ge}-\mathrm{Ge}$ bond distances which differ from each other with the values of 2.659(1) $\AA$ (molecule 1) and 2.677(1) $\AA$ (molecule 2). The sum of $\mathrm{Ge}-\mathrm{N}$ bond distances of $7.218 \AA$ in molecule 1 is about $0.096 \AA$ smaller than that found in molecule 2 $(7.314 \AA)$. This indicates that the former molecule is somewhat more crowded than the latter one.

There are three tetranuclear derivatives [18-20] which contain two crystallographically independent molecules. In 
red $\mathrm{Ge}_{4}\left(\mathrm{SitBu}_{3}\right)_{4}$ [18] four germanium atoms form almost a regular tetrahedron with $\mathrm{Ge}-\mathrm{Ge}$ bond distances from 2.431(2) $\AA$ to 2.447(2) $\AA$ and $\mathrm{Ge}-\mathrm{Ge}-\mathrm{Ge}$ angles from $59.62(7)^{\circ}$ to $60.10(7)^{\circ}$. Each $\mathrm{Ge}(\mathrm{I})$ atom carries a terminal $\mathrm{SitBu}_{3}$ group with mean $\mathrm{Ge}-\mathrm{Si}$ bond distance of 2.383(4) $\AA$.

The remaining tetranuclear derivatives [19, 20] contain $\mathrm{Ge}_{4} \mathrm{~S}_{10}{ }^{-4}$ [19] or $\mathrm{Ge}_{4} \mathrm{~S}_{9}^{-2}$ [20] anions, which posses an adamantane-like structure. Structure of $\mathrm{Ge}_{4} \mathrm{~S}_{10}{ }^{-4}$ anion is shown in Fig. (1). The tetrahedral anions are composed of nearly regular tetrahedral Ge(IV) centres, each having one terminal $\mathrm{S}$ and three doubly bridging $\mathrm{S}$ atoms (Table 2).

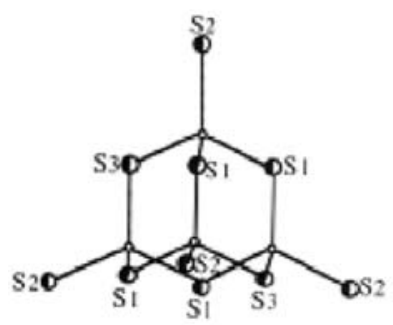

Gel

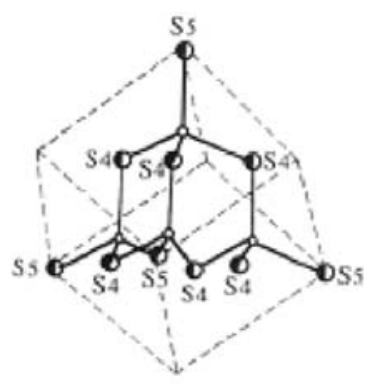

Ge2
Fig. (1). Structure of $\left[\mathrm{Ge}_{4}(\mu-\mathrm{S})_{6}(\mathrm{~S})_{4}\right]^{4-}$.

There are two oligonuclear derivatives, brown (2,2,2crypt-K $)_{6}\left(\mathrm{Ge}_{9}\right)\left(\mathrm{Ge}_{9}\right) .0 .5$ en [21] and deep red (2,2,2-crypt$\mathrm{K}_{6}\left(\mathrm{Ge}_{9}\right)\left(\mathrm{Ge}_{9}\right) .1 .5$ en [21] which are isostructural and contains two the $\mathrm{Ge}_{9}{ }^{-3}$ clusters. The structure of a $\mathrm{Ge}_{9}{ }^{-3}$ unit is shown in Fig. (2). It is depicted as a tricapped non-regular trigonal prism. In brown derivative the $\mathrm{Ge}-\mathrm{Ge}$ bond distances range from $2.572(2)$ to $2.817(2) \AA$ in one $\mathrm{Ge}-\mathrm{Ge}_{8}$ cluster and from 2.562 to $2.853(2) \AA$ in the other one $\mathrm{GeGe}_{8}$ cluster. In deep red derivative the values are $(2.527(2)-$ $2.837(2) \AA$ and $2.562(2)-2.904(2) \AA$ respectively (Table 2 ). a)

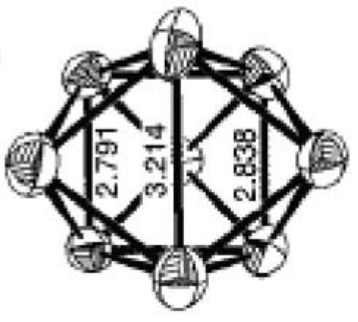

b)

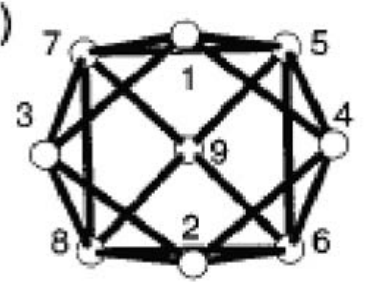

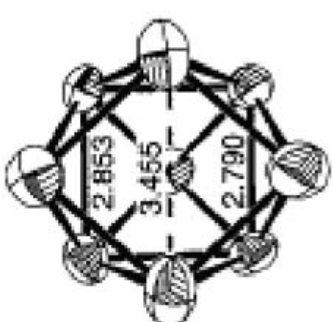

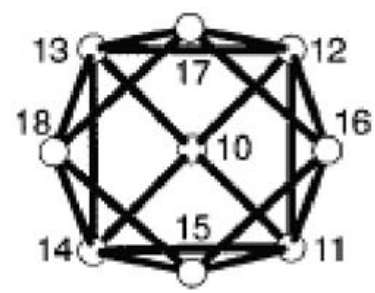

Fig. (2). View of the $\mathrm{Ge}_{9}{ }^{3-}$ anions: (a) Cluster A (left) and B (right) With thermal ellipsoids shown at $50 \%$ probability level, atom labels see (b). (b) The same clusters shown as parallel projection emphasizing the different Shapes of the two polyhedra.

Structure of colourless $\mathrm{GeCl}_{3}\left(\mathrm{NPMe}_{3}\right)$ [22] shows that in the unit cell are two symmetry related monomers containing tetracoordinated germanium $\left(\mathrm{GeCl}_{3} \mathrm{~N}\right)$, and one crystallographically centrosymmetric dimer with a planar four membered $(\mathrm{GeN})_{2}$ ring exhibiting trigonal bipyramidal configuration around each $\mathrm{Ge}(\mathrm{IV})$ atom $\left(\mathrm{GeCl}_{3} \mathrm{~N}_{2}\right)$. The very short Ge $-\mathrm{N}$ bond length of 1.737(8) $\AA$ in the monomer is indicative of the involvement of a $\mathrm{p} \pi-\mathrm{d} \pi$ component. At least two types of isomerism exist in the example, distortion (monomer) and configuration isomerism (four coordinate monomer and pentacoordinated dimer) (Table 2).

\section{CONCLUSIONS}

This review summarises the crystallographic and structural data for twenty coordination compounds of germanium which are distortion isomers. Another one [22] contains two types of isomerism, distortion and configuration. Remainders [4-21] contain two crystallographic independent molecules differ mostly by degree of distortion.

Germanium exists in an oxidation states $+1,+2$ and +4 , including non-integral $\mathrm{Ge}_{9}{ }^{3-}$. Of these +4 oxidation state is the most common. The isomers are mostly colourless, yellow, but there are some red examples. The nuclearity of isomerism is mono-, di-, tetra - and nanonuclears.

The $\alpha$ - and $\beta-\mathrm{Ge}\left(\eta^{4}-\mathrm{tpp}\right)(\mathrm{MeO})_{2}[3,4]$ isomers are different not only by degree of distortion, but also by crystal class, $\alpha$ - being monoclinic and $\beta$ - tetragonal. In additional $\alpha$ - contains two crystallographically independent molecules. There are six derivatives $[5-8,11,18,20]$ which are monoclinic, six $[15,17,21,22]$ are triclinic, three $[9,10,16]$ are orthorhombic and one [9] is cubic. Colourless $\left(\mathrm{NMe}_{4}\right)\left[\mathrm{GeCl}_{3}\right]$ at $424 \mathrm{~K}$ is cubic [12] is orthorhombic at $293 \mathrm{~K}$ and $190 \mathrm{~K}$ [12$14]$ and is monoclinic at $160 \mathrm{~K}$ [14].

There is a variety of inner coordination spheres around the germanium atom. In $\mathrm{Ge}(1)$ complex is tetrahedral (Ge$\mathrm{SiGe}_{3}$ ). In $\mathrm{Ge}(\mathrm{II})$ complexes are trigonal planar with varied degrees of distortion: $\mathrm{GeCl}_{3}, \mathrm{GeI}_{3}, \mathrm{GeI}_{2} \mathrm{P}$ and $\mathrm{GeSi}_{2} \mathrm{Ge}$; and tetrahedral $\mathrm{GeN}_{4}$. The environment around $\mathrm{Ge}(\mathrm{IV})$ are tetrahedral: $\mathrm{GeS}_{4}, \mathrm{GeO}_{2} \mathrm{~N}_{2}$; trigonal bipyramidal: $\mathrm{GeO}_{4} \mathrm{~N}$, $\mathrm{GeO}_{3} \mathrm{NBr}$ and $\mathrm{GeCl}_{2} \mathrm{~S}_{2} \mathrm{O}$, and compressed tetragonal bipyramidal $\mathrm{GeN}_{4} \mathrm{O}_{2}$. Most axial positions are occupied by $\mathrm{O}$ donor atom ligands.

This review, together with its precursors [23, 24] represents the first overall survey of the structural data of isomers for the non-transition sub-group $(\mathrm{Ge}-\mathrm{Sn}-\mathrm{Pb})$. Interesting while in lead complex chemistry exists several types of isomers included distortion (60\%) ligand $(20 \%)$, coordination $(12 \%)$ and polymerization (8\%) [24], in tin coordination chemistry distortion $(96.5 \%)$ and cis - trans $(3.5 \%)$ [23], in the germanium coordination chemistry distortion isomerism with one example which contains in the same crystal distortion and coordination isomers, and it is rarity. Generally, the distortion isomerism in this sub-group by far prevails.

\section{ACKNOWLEDGEMENTS}

The authors wish to thank those who gave permission for reproduction of original figures, and the Ministry of Education of the Slovak Republic, APVV-20-005504 and VEGA 1/0353/08 grants for financial support.

\section{ABBREVIATIONS}

$\mathrm{tBu}=$ terc-butyl 


$$
\begin{array}{ll}
\mathrm{Bz} & =\text { benzyl } \\
\text { cryp } & =\text { cryptate } \\
\mathrm{c} & =\text { cubic } \\
\mathrm{en} & =\text { ethylendiamine } \\
\mathrm{Et} & =\text { ethyl } \\
\mathrm{EtO} & =\text { ethoxy } \\
\mathrm{m} & =\text { monoclinic } \\
\mathrm{Me}_{2} \mathrm{en} & =\text { N,N-dimethylethylenediamine } \\
\mathrm{MeO} & =\text { methoxy } \\
\mathrm{or} & =\text { orthorhombic } \\
\mathrm{pi} & =\text { pilocarpine } \\
\mathrm{PPh} & =\text { triphenylphosphine } \\
\mathrm{iPr} & =\text { isopropyl } \\
\mathrm{tg} & =\text { tetragonal } \\
\mathrm{tpp} & =\text { tetraphenylporphinato } \\
\mathrm{tr} & =\text { triclinic }
\end{array}
$$

\section{REFERENCES}

[1] Holloway, C.E.; Melník, M.; Main Group Met. Chem., 2001, 24, 681.

[2] Melník, M. Coord. Chem. Rev., 1982, 47, 239.

[3] Mavridis, A.; Tulinsky, A. Inorg. Chem., 1976, 15, 2723.

[4] Schwu-Juian, L.; Yao-Jung, C.; Jyh-Houng, C.; Feng-Lin, L.; SueLein, W.; Shing-Shing, W. Polyhedron, 1997, 16, 2483.

[5] Wegner, G.L.; Jockisch, A.; Schonidbaur, H. Z. Naturforsch., 1998, $53 b, 430$.
[6] Fregersley, S.; Rasmussen, S.E. Acta Chem. Scand., 1968, 22, 2541.

[7] Inoguchi, Y.; Okui, S.; Mochida, K.; Itai, A. Bull. Chem. Soc. Jpn., 1983, $58,974$.

[8] Ovchinnikova, Y.E.; Struchkov, Y.T.; Baryshok, V.P.; Ovchinnikova, Z.A.; Voronkov, M.G. Dokl. Akad. Nauk SSSR, 1993, 330, 464; Engl. Ed., p. 269.

[9] Gorkova, S.N.; Gusev, A.I.; Alexeev, M.V.; Segelman, I.R.; Gar, T.K.; Khromova, N.Y. Zh. Strukt. Khim., 1983, 24, 83; Engl. Ed., p. 238.

[10] Dräger, M. Z. Anorg. Allg. Chem., 1990, 589, 199.

[11] Balch, A.L.; Coruman, C.R.; Olmstead, M. J. Am. Chem. Soc., 1990, 112, 2963.

[12] Möller, A.; Felsche, J. J. Appl. Cryst., 1979, 12, 617.

[13] Depmeier, W.; Möller, A.; Klaska, K.H. Acta Crystallogr. B, 1980, 36,803 .

[14] Fütterer, K.; Depmeier, W.; Petricek, V. Acta Crystallog. B, 1995, 51,768 .

[15] Kira, M.; Iwamoto, T.; Mamyama, T.; Kabuto, C.; Sakurci, H. Organometallics, 1996, 15, 3767.

[16] Ellis, D.; Hitchcock, P.B.; Lappert, M.F. J. Chem. Soc. Dalton Trans., 1992, 3397.

[17] Pfeffer, J.; Muringgelle, W.; Notmeyer, M.; Meller, A. Chem. Ber. 1989, 122, 245.

[18] Wiberg, N.; Hochmuth, W.; Nötth, H.; Appel, A.; SchmidtAmelunxen, M. Angew. Chem. Int. Ed. Engl., 1996, 35, 1333.

[19] Piran, J.Y.; Achak, D.; Louer, M.; Louer, D. Chem. Mater., 1994, 6,8278 .

[20] Nellis, D.M.; Younghee, K.; Kemin, T.; Koch, S.; Parise, J.B. J. Chem. Soc. Chem. Commun., 1995, 541.

[21] Fässler, T.F.; Schütz, U. Inorg. Chem., 1999, 38, 1866.

[22] Scheldrik, W.S.; Schomburg, D.; Wolfsberger, W. Z. Naturforsch., 1978, 33b, 493.

[23] Melník, M.; Garaj, J.; Valent, A.; Kohutova, M. Trends Inorg. Chem., 2006, 9, 45

[24] Melnik, M.; Garaj, J.; Holloway, C.E. Main Group Met. Chem., in press. 